\title{
Research on Career Development Strategy of Young Teachers in Colleges and Universities
}

\author{
Dai Yan \\ School of Humanities \\ Kunming Medical University \\ Kunming, China, 650500 \\ 1015916577@qq.com
}

\begin{abstract}
As a group that undertakes the task of talent training, the comprehensive quality and professional knowledge level of teachers in Colleges and Universities determine the quality of talent training. In view of the problems faced by young teachers in Chinese colleges and universities in their career development, the paper analyzes and discusses the career development of young teachers in universities from the perspective of theory and practice, and puts forward corresponding countermeasures. In order to promote the career development of young teachers in universities, first of all, it is necessary to strengthen policy support, improve management system, and develop a career planning chain. Secondly, young teachers in colleges and universities should establish their own scientific guidance view, correctly understand the fundamental problems and play their own main roles. Finally, it is also necessary to establish a learning organization to promote the career development of young teachers in universities.
\end{abstract}

Keywords -University; Young teachers; Career development; Influence factors; Countermeasures

\section{INTRODUCTION}

In all parts of the world, becoming a professor is the career pursuit of most young teachers in university. In recent years, there is a common phenomenon in Chinese universities, which is teacher teaching cannot become professor, the professor does not teach, heavy scientific research, light teaching. This has a negative impact on the career development of university young teachers in China. For young teachers (age 35 and below) that occupy a large proportion of university teachers, as the main force of the future development of university, they are the future of the university. The career development of young teachers has increasingly become the focus of attention of colleges and education management departments. Young teachers at the beginning of their careers have a weak professional foundation, lack of social resources; there are many problems of their career development. The career development of university young teachers is a dynamic and flexible process. Through career development planning, young teachers can realize the continuous improvement and development of their professional quality. So it is of special significance to study the career development strategies of university young teachers.

\section{The Status Quo Of Young Teachers In CHINESE UNIVERSITIES}

\section{A. There Are Many Young Teachers in Chinese Universities}

The statistics of University young teachers in the official website of the Ministry of Education of China is exhibited in Table I. The Table I shows that from 2003 to 2012, the proportion of young teachers in Chinese universities has a downward trend, however, the proportion of young teachers is still more than $40 \%$, and so young teachers are still a huge group among college teachers.

TABLE I STATISTICS ON THE NUMBER OF YOUNG TEACHERS IN CHINESE UNIVERSITIES FROM 2003 TO 2012

\begin{tabular}{|c|c|c|c|}
\hline Years & $\begin{array}{c}\text { Total Number of Full-time Teachers, } \\
\text { Unit: Person }\end{array}$ & $\begin{array}{c}\text { Number of Young Teachers, Unit: } \\
\text { Person }\end{array}$ & $\begin{array}{c}\text { The Proportion of Young } \\
\text { Teachers/\% }\end{array}$ \\
\hline 2003 & 724658 & 340852 & 47.04 \\
\hline 2004 & 868393 & 405729 & 46.72 \\
\hline 2005 & 965839 & 463906 & 48.03 \\
\hline 2006 & 1075989 & 520130 & 48.34 \\
\hline 2007 & 1168300 & 566813 & 48.52 \\
\hline 2008 & 1237451 & 591255 & 47.78 \\
\hline 2009 & 1295248 & 608928 & 47.01 \\
\hline 2010 & 1343127 & 620745 & 46.22 \\
\hline 2011 & 1392676 & 628780 & 45.15 \\
\hline 2012 & 1440292 & 634503 & 44.05 \\
\hline
\end{tabular}




\section{B. Difficulty in Professional Title Evaluation}

According to the statistics [1], as of 2013, among college teachers in China, young teachers have a lower proportion of intermediate and senior professional titles. In Chinese universities, the titles of teachers are divided into three levels, namely, primary, intermediate and senior. There are strict quantitative restrictions on each level. The promotion of professional titles is closely related to the survival and development of teachers. Through professional title promotion, young teachers can not only improve their social status, obtain better income to improve the family's living environment, but also have more resources on their own development roads and obtain more academic exchange opportunities to promote their own growth.

In Chinese universities, the professional title assessment universally emphasizes the achievements of scientific research and neglects the effect of teaching. The reasonable evaluation standard should be the combination of professional theory level, teaching quality and scientific research results. In reality, many universities have clearly stipulated the number of papers and the project of conducting scientific research in the process of professional title evaluation. However, the teaching attitude, the teaching effect and the student evaluation of teaching are not reflected in the title assessment. As the main force of teaching, young teachers spend most of their energy on teaching, and only a limited amount of time and energy on scientific research. As a result, the number of scientific research achievements often falls short of the requirements, thus causes difficulty in the professional title promotion.

\section{Lack of Teaching Ability}

A survey result as in [2] shows that new college teachers in China generally come from non-teacher colleges, although they have received systematic professional education, basically have a good professional research literacy and strong research capabilities, but they have not received systematic teacher vocational education, lack of education scientific knowledge and basic education teaching training. Therefore, young teachers in China's colleges, especially new teachers, have a general lack of teaching ability. As a matter of fact, young teachers, especially new teachers, are the main body responsible for teaching tasks. This situation will have an adverse effect on the quality of personnel training in colleges and universities.

\section{Lack of Scientific Research Awareness}

GUO has launched a survey on young teachers' awareness of scientific research in Chinese universities [3]. The survey results show that most of the young teachers do not have strong scientific research awareness, only $20 \%$ of the young teachers have a strong research interest, young teachers' research motivation is more differentiated, personal investment is less. The scientific research awareness of the young teachers in colleges is relatively inadequate, which has adverse effects on their own professional title upgrading assessment.
Scientific research is the responsibility that university young teachers must take and is also the way they grow. However, many young teachers in university do not have a clear understanding of scientific research and are not enthusiastic about scientific research. They cannot correctly position the relationship between teaching and scientific research. There are many factors that affect young teachers' research enthusiasm. The main reasons are heavy teaching tasks, shortage of funds for scientific research, lack of scientific research conditions, unfair scientific research evaluation. Besides, many young teachers' motives for scientific research are not from the heart, but with great utilitarianism. Many people force themselves to carry out research activities just for the sake of some utilitarian things, without really realizing the value and significance of scientific research.

\section{E. Lack of Effective Career Planning}

In Chinese Universities, most newly recruited young teachers do not have a clear career planning, and always ready to leave educational posts through other examinations [4]. With a clear career planning goal, and actively preparing for the future work, such teachers often have a desire to achieve higher achievements. They always stare at the target, continue to achieve a phased goal, and are more likely to achieve results, whether teaching or scientific research. Reasonable career planning enables young teachers to recognize and evaluate themselves correctly, and then to re locate their own values according to their own characteristics, professional expertise, interests and hobbies, to fully tap their potential and resource advantages, and to develop their strengths and avoid weaknesses. Based on the content and reality of the planning, compare the development situations, find gaps, and adjust their career development path in time.

At present, the career development goals of young teachers in Chinese universities are becoming increasingly clear. Career development is a process in which individuals gradually achieve their career goals and constantly formulate appropriate goals. The characteristics of the career development of young teachers in Chinese universities are gradually emerging. From the professional point of view, college teachers should have a richer knowledge reserve and stricter academic training than the general occupation. They should obey the ethics of the teacher occupation, and should have the technical ability and research ability to promote knowledge updating and academic progress, especially young teachers, should become a model and a force in this regard. The career development stage of young teachers in universities has gradually become clear. Using the time series method, teachers' professional development process can be divided into different stages, emphasizing that teachers' career development characteristics change with time. The representative theories are: Fuller's attention stage theory, Burton's teacher professional life cycle stage theory, Liss Wood's psychological development stage theory and Lacey's teacher professional development stage theory [5]. University young teachers should adjust their mentality, make reasonable plans, and adapt to their own career development requirements. 


\section{INFLUENCING FACTORS OF CAREER DEVELOPMENT OF UNIVERSITY YOUNG TEACHERS}

College teachers as a social profession form a certain career development expectation and planning, which is the result of a combination of external factors and various factors. The subjective factors of teachers themselves are indispensable, but the influences of the family, school and society cannot be ignored, these factors will have a great impact on the career development of teachers, and different influence factors will have different effects. For example, the positive influence factors will stimulate the teachers to actively pursue the career development, and the negative factors may block, suppress or even interrupt the career of the teachers. In this regard, Professor Fessler of Johns Hopkins University in the United States put forward the influence factor theory on the development of teachers' career development. All the influencing factors are attributed to two major categories, namely, individual environmental factors and organizational environment factors. At present, the influencing factors of career development of young teachers in Chinese universities are also mainly reflected on these two aspects.

First of all, from the perspective of personal environment, it mainly includes family factors and personal development factors. Specifically, family plays a vital leading role in career preparation. For university young teachers, they are in the start and rise period of the career, the work task is heavy, the work pressure is heavy, the research workload is heavy, they have higher requirements for a harmonious and happy family environment. Therefore, different family conditions will have different guiding role on their psychology. In addition, the influence of personal development factors cannot be overlooked. Such as personal character, interest, knowledge accumulation and scientific research ability will have an impact on the career development of young teachers in universities.

Secondly, from the perspective of organizational environment, the organizational environment mentioned here includes both the college environment where teachers work and the social environment. Whether a person can succeed in career development is inseparable from organizational training, leadership trust, colleague support and social identification. The career development of young teachers is closely related to the organizational culture of universities, the governing style of leaders and the macro-policy of society. The school is a unique organizational system, and the organizational culture of university is a value concept system for its members to identify and follow in the process of interaction between educational practice and various environmental factors. As the spiritual pillar of the school organization members, this implicit psychological hint exerts a subtle influence on teachers' psychology, emotion and values, which affects the concept of teachers' career development. At the same time, the principal's management style and school management style have obvious effects on teachers' career. The teacher's response is very positive when the principal's management type is integrated with the teacher's career maturity. In a fair, respectful and positive management system, teachers will be full of confidence in schools and their own teaching work, and will rationally plan and strive to achieve their own career development goals. In addition, changes in national policies, educational reforms, and progress in science and technology will have impact on teachers' career.

Of course, some special external factors also affect the career development of university young teachers. For example, the current employment oriented school concept in some universities has increased the work burden and difficulty of young teachers, and the constant adjustment of professional structure has influenced the professional adaptability and professional ability of young teachers.

\section{COUNTERMEASURES FOR STRENGTHENING AND IMPROVING THE CAREER DEVELOPMENT OF YOUNG TEACHERS IN COLLEGES AND UNIVERSITIES}

We should fully mobilize the resources and strength of the society, schools and teachers themselves to form a joint effort to promote the career development of young teachers in universities.

Strengthen policy support. On the one hand, we should strengthen the support for higher education in policies and regulations, increase the effective investment in the construction of hardware and soft environment, improve the salary and welfare of the young teachers, and ensure the quality of the teaching and life of the young teachers in universities. On the other hand, we should establish a fairer and reasonable scientific research project declaration and approval procedure, optimize the process and structure of the evaluation of teachers' professional titles, and strive for national policy support and teaching fund support. The relevant policies should be inclined to the group of young teachers.

Improving the management system and formulating the chain of career planning, creating a supportive policy environment. Career management expert, Professor Edgar Sean of MIT Sloan business school puts forward the concept of Career Anchor, which is when a person has to make a choice; he or she will never give up the crucial thing in his career. First of all, university must determine the career management tasks of teachers in different career cycles. At all stages of teacher career development, according to the differences of teachers' work tasks, working conditions and professional behaviors, provide career guidance and training for young teachers, set up the correct Career Anchor. Secondly, establish a career development-oriented performance appraisal system; evaluate the reality and rationality of teachers' development goals. Evaluate the individual target behavior of teachers, and scientifically co-ordinate and treat differently, make it more scientific, comprehensive and fair, with long-term guiding role. Once again, strengthen the construction of young teachers, constantly improving young teachers' teaching level and scientific research ability; create opportunities for young teachers in education training, education promotion and further study abroad.

Establish a scientific concept of guidance and correctly face practical problems. University young teachers should adhere to the ethics of collectivism and education, and formulate career development plans in combination with the development of school and the needs of their own 
development. In the cause of education, university young teachers should seek to locate their core skills in their discipline setting and guarantee their continuous improvement in their skills, correctly handle the pressure and contradiction in career development, and enhance the healthy psychological adjustment ability, set up the concept of lifelong learning, deepening the business level and giving full play to its own main role, and becoming an excellent professional person with certain academic standards and attainments in the subject industry.

Establish learning organization to promote the career development of university young teachers. Learning organization is undoubtedly an ideal mode to achieve individual career planning and organizational management incentives. At the same time, the real and effective mode of promoting the career development of university young teachers should be an organic combination of the main needs and the external support on the basis of the youth teachers as the center. Learning organization is a kind of organizations that can consciously, systematically and continuously create, accumulate and use knowledge resources, try to change or redesign itself to adapt to the changing internal and external environment, so as to maintain sustainable development and competitive advantages. The learning process in a learning organization is a process of self-building by individuals. It emphasizes independent design and independent management, so building a learning organization based on the theory of learning organization is a strategy to effectively promote the career development of university young teachers. In this organization, opportunities for continuous learning can be created; professional discussions and dialogues can be carried out among peers. And it can encourage cooperation and team learning, and establish a learning sharing system. Through the combination of organization and environment, members are promoted towards common vision.

\section{CONCLUSION}

In order to promote the career development of young teachers in colleges and universities, first of all, it is necessary to strengthen policy support, improve management system, and formulate career planning chain. Secondly, young teachers in colleges and universities should establish their own scientific guidance view, face the real problems correctly and play their own main role. Finally, establish learning organization to promote the career development of young teachers in universities.

\section{REFERENCES}

[1] Zhou G.J, Tong S.S, "Analysis of professional development of new teachers in colleges in the background of professionalization," Journal of Zhejiang University of Technology (Social Science), Vol. 9, pp. 381-385, 2010.

[2] Wang G.M, Shen Y.C, "Research on Career Development Planning of Young Teachers in Universities," Education and Vocation, Vol.15, pp. 46-47, 2009

[3] Guo P, Yang Y, "Research on the current situation and Countermeasures of young college teachers' career development," China Youth Study, Vol. 7, pp. 111-113, 2010.

[4] Zhao L.F, Cai Y.M, "Investigation and analysis of career planning for young teachers in Colleges," Acta Universitatis Medicinalis Nanjing (Social Science), Vol.2, pp. 148-151, 2013.

[5] Wang J.H, "A research on current situations of college teachers' academic rank assessment and engagement and solutions," Teacher Education Research, Vol.25, pp. 18-22, 2013. 